\title{
University-Industry Links in Slovakia: What are the Factors Underlying the Number of Interactions with Industry?
}

DOI: 10.12776/QIP.V23I1.1137

\author{
Slávka Klasová, Iveta Korobaničová, Oto Hudec
}

Received: 28 October 2018 Accepted: 16 January 2019 Published: 31 March 2019

\begin{abstract}
Purpose: The main aim of the paper is to investigate the determinants of university-industry links, considering the number of contracts with industry as an output variable. Also, the spatial dimension of contracts is examined, explaining to what extent U-I cooperation is anchored regionally or nationally.
\end{abstract}

Methodology/Approach: The paper uses a unique dataset comprising 1,158 contracts with industry at the 25 faculties belonging to five technical universities in Slovakia. Negative binomial regression analysis is used to evaluate the determinants for academic engagement in contract research.

Findings: Empirical findings reveal the impact of the factors such as age, personnel structure, the intensity of supervising and experience in research projects financed by public authorities, mattering more than patenting or teaching intensity in the propensity of researchers to engage with industry.

Research Limitation/implication: The outcomes only concern technical universities in Slovakia, and there is still room for analysis of other faculties comprising other subject areas. Since there is no longer time series data, the 2014-2016 timeframe did not permit to explore additional contexts in the model.

Originality/Value of paper: Foremost, this is the first attempt to investigate the relationship between different factors and the level of contract research in Slovakia, making several contributions to the existing literature.

Category: Research paper

Keywords: university's third mission; contract research; technology transfer; university-industry links 


\section{INTRODUCTION}

Universities have traditionally been perceived as elite institutions, places of teaching and learning rooted in quality research. In the early 19th century, the Humboldtian model of higher education emerged and was introduced in Europe, combining and integrating research and education and developing knowledge of general nature and ideas of cultural knowledge. Over the years, the new tendencies in terms of focus on knowledge for the sake of solving the compelling problems of society appeared (Audretsch, 2014), and universities have widened their activities beyond teaching and academic research. Thus, many universities have taken action by developing a third mission (entrepreneurship and technology transfer) in order to initiate the process of shifting from the ivory tower atmosphere towards the philosophy of academic capitalism (Novotny, 2008). The roots of entrepreneurial university concept trace back to the late 19th century when the lack of a formal research funding system in the U.S. placed a premium on individual and collective initiatives for obtaining resources to support original research (Etzkowitz and Leyedesdorff, 2000). The cut-off resources from the government together with increasing competition for research funds and skilled students have put universities under pressure to reconsider the way they function and activities portfolio (Hudec, 2017). Universities have extended their role as core actors within regional innovation ecosystems and have established new and diverse opportunities for effective knowledge transfer. Predominantly the pull model has slowly replaced a closed system characterised by the presence of push model of innovation and universities have started to foster links with industry to facilitate technology transfers (Perkmann et al., 2013). Within triple helix system (University-Industry-Government), universities act as a generator of knowledge and also a conduit between government and industry (D'Este and Patel, 2007). More recently user-driven innovation models have emerged adding a fourth stakeholder group to the triple helix model, namely end-users. Universities have recognised the need to strengthen their collaboration and cooperation between quadruple helix stakeholders (Carayannis et al., 1998). Accordingly, specialised infrastructure consisting of technology transfer offices (TTOs), science parks and incubators have been established at universities to serve as an interface between the diverse stakeholders as well as to accomplish a third entrepreneurial mission (Ramaciotti and Rizzo, 2014).

Undoubtedly, there is potential at universities to generate innovations, provide expertise to industrial companies, develop new technologies and products and deliver them to the business sector (Capaldo et al., 2016; Hunady, Orviska and Pisar, 2018). Various channels exist through which academic knowledge and technology are transferred to industry. Recently, there has been burgeoning empirical literature dealing with the more easily measurable university-industry (U-I) interactions such as patenting, licensing and generation of spin-off companies (Shane, 2004; Phan and Siegel, 2006; Rothaermel, Agung and Jiang, 2007). Besides the one-way commercialisation of academic research, there are 
other knowledge exchange channels. This paper focuses on one of the channels, namely contract research, which is defined as a paid-for service performed by university researchers for external clients (Perkmann and Walsh, 2007). In comparison to licensing, which does not necessarily require close relationships between university researchers and industry users, links based on contract research require greater relational involvement. Research contracts are also highlighted as a mean for co-creational knowledge transfer between universities, industry, government and end-users within open innovation quadruple helix ecosystem (McAdam et al., 2012). Despite its evident importance, only a few studies about industrial contract research are available (Spithoven, 2016). Contract research has largely been unobserved (D'Este and Patel, 2007) as much of the literature on U-I links have paid more attention to patenting and spin-off activities. However, a number of authors have confirmed contract research more relevant channel than licensing (Cohen, Nelson and Walsh, 2002; Roessner, 1993; Schartinger et al., 2002). Therefore, the purpose of this paper is to address these gaps by exploring the drivers of this type of U-I link, utilising a unique dataset comprising more than 1,158 research contracts in the 25 faculties belonging to the 5 different technical universities in Slovakia.

In this study, the five technical universities in Slovakia were chosen as an empirical case as they do more applied research what is also reflected in the higher amounts of research contracts. For instance, biotechnology academic knowledge generally seems to be transferred to industry through university spin-offs. However, contract research is more frequent in engineering disciplines (Meyer-Krahmer and Schmoch, 1998; Schartinger et al., 2002). Technical universities were used to have close links with local firms, and there have always been researchers involved in U-I contract research, as a one-shot or a repeating activity (Perkman et al., 2013). Additionally, Slovakia is a compelling case of a post-communist Central and Eastern European countries (CEE) where higher education institutions have experienced decades of central planning and political control, emphasis on technology fields and isolation from Western countries. Due to massive industrialisation, high centrally given student quota rates in engineering studies were applied to match the centrally planned requests of state-owned enterprises. Moreover, the primary focus of universities in Central Europe, especially in the 1990s, has been on the teaching mission (Kwiek, 2012), to some extent based on Humboldt's style (Audretsch, 2014). The HEIs, however, were allowed to perform contract research, which was called secondary economic activity. Privatisation and economic decline affected the volume of contract research negatively, but its older forms have survived to some extent. Today, the position of U-I contract research is largely influenced by to the adoption of new roles in science and research - in particular, the budget for public universities has become more dependent on the academic research performance. Also, less emphasis on contract research might be related to third university role, i.e. promoting commercialization of own research rather than responding to business sector requirements. At last, a new factor affecting contract research after entering the European Union appeared, namely 
accessibility of public and European funds. The efforts to promote entrepreneurial attitudes at universities in Europe are at odds with the institutional history of central planning and control (Franzoni and Lissoni, 2009). Hence, it would be interesting to find out to what extent university's direction from education towards its new roles and a more innovative orientation has changed. In our study, the determinants of creating U-I partnerships are investigated in terms of the number of contracts and the income they generate at faculties. In addition, the spatial dimension of contracts is examined, explaining to what extent U-I cooperation is anchored regionally or nationally.

This paper is organised as follows. In Section 1, we review the literature on university-industry knowledge transfer channels as well as on the factors affecting the formation of contract research with industry. Section 2 introduces the data and methodology used in this paper. Section 3 and 4 present the main empirical results. In the last Section 5 the main findings are interpreted and discussed and recommendations for future research are proposed.

\section{UNIVERSITY-INDUSTRY COLLABORATION}

U-I collaborations and their impact on innovation processes have been a longstanding object of analysis in numerous studies (Cohen, Nelson and Walsh, 2002; Schartinger et al., 2002; Perkmann and Walsh, 2007). Generally, knowledge interactions can be studied from both sides; from the view of the firm and the view of the university. The knowledge flow from universities to industry has traditional forms such as the hiring of recent graduates, conferences, publications and services; personal training, information exchange, consultancy, temporary exchange of staff (Dutrénit and Arza, 2010). The commercial channel transfers of intellectual property include patenting, licensing and commercialisation, and university spin-outs (Cohen, Nelson and Walsh, 2002). In comparison, the bidirectional academic engagement model is defined as a knowledge-related collaboration of academic researchers with non-academic companies, where universities, industries are co-creators of research (Sengupta and Ray, 2017). Bidirectional U-I relationships comprise activities such as collaborative research, contract research, knowledge networks and scientific-technological parks, etc. (Capaldo et al., 2016). From a private-sector perspective, the benefits of collaborating with academia have been found to be unambiguously positive (Hottenrott and Thorwarth, 2011). Industry can benefit from the access to new knowledge, complementary know-how and cutting-edge technology, access to research facilities, risk reduction or sharing, or shortening the product life cycle (Ankrah and Al-Tabbaa, 2015). Equally, universities may benefit from the complementary funding to already existing public financing, initiation of new ideas, hiring additional researchers, investment in lab equipment, employment of new knowledge into the learning process, commercialisation of their intellectual property as well as internships and placement opportunities for students (Lee, 2000). The interaction between any segment of the higher education system and 
industry targets knowledge and technology exchange in many channels - joint research, contract research, informal contacts, mobility or training (MeyerKrahmer and Schmoch, 1998; Schartinger et al., 2002). The bilateral approach to U-I co-operation has since been broadened as "multi-way" to accentuate the role of actors such as governmental agencies (Meyer-Krahmer and Schmoch, 1998). This has a close connection to innovation networks and the theories of innovative systems (Furman, Porter and Stern, 2002; Schiuma and Lerro, 2008). Institutional factors, potential capabilities of a spatial system to convert knowledge into innovation can be expressed in the framework of national (NIS) or regional (RIS) innovation system theory (Hudec, 2015; Prokop, Stejskal and Kuvíková, 2017). In the centrally planned economy, there was a national science and technology system in operation instead. Transition to a market economy should gradually lead to the decentralisation and strengthening of regional innovation systems considered to be more effective for innovation performance due to the exchange of tacit knowledge. That is why, in the example of contract research, we are looking at the degree of regional cooperation. Collaborative or joint research refers to formal collaboration arrangements among organisations aimed at co-operating on $R \& D$ activities. In Europe, these projects are often subsidised by public funding. e.g. the framework programmes of the European Commission (Capaldo et al., 2016). By contrast, also unlike in collaborative research, contract research is more one-way in the sense that company unilaterally specifies requirements, type of expertise or service and the researchers carry out the assignment against payment. This type of research has low entry costs and requires low levels of absorption capacity.

\subsection{Factors Influencing the Formation of Contract Research}

Despite the increasing attention devoted to the determinants of U-I linkages, there is still little consensus as to what explains the formation of such linkages (Giuliani et al., 2010). U-I creation has been emphasized as a multi-level phenomenon, determined by both the characteristics of individuals as well as the organisational and institutional context in which they work (Perkmann et al., 2013). This study is aimed at the faculties and the importance of two groups of factors on the propensity of their engagement in contract research with industry organisational (academic quality, reputation, teaching intensity) and institutional (the environment in which the research is undertaken).

\section{Organisational Context}

The most salient organisational determinant for academic engagement is the academic quality. Based on the assumption that the older the faculty, the higher its prestige and the higher its impact on the number of contracts with industry (Sengupta and Ray, 2017), we control for the faculty age (F_AGE). As the size of the faculty may strongly affect the volume of industry interactions (D'Este and Patel, 2007), each independent variable is divided by the number of academic staff (professors, associate professors, and assistants who have full-time tenured or tenure-track appointments) (STAFF). A high share of senior researchers (the 
personnel structure, measured as researchers with the title of Professor) indicates more experienced researcher capacity and a higher probability of engaging with industry (D'Este and Patel, 2007; Schartinger, Schibany and Gassler, 2001). Firms are likely to feel more confident about advice obtained from tenured professors (Giuliani et al., 2010). The independent variable (PROF/NON_PROF) is measured as the ratio of the number of professors to the number of other researchers (associate professors and assistants). Faculty reputation is related to the quantity and quality of its publications. There may be a trade-off between publications and U-I linkages. Researchers receiving more funding from industry and occupied with reports have less time capacity to academic research (Jensen and Thursby, 2001). Faculties with a high publication record exhibit a strong commitment in terms of time and orientation at the expense of knowledge transfer outwith the academic community. On the other hand, high output of publications is a sign of expertise and firms may prefer to interact with academics with established scientific reputations rather than with researchers who are less well known scientifically. The independent variable (SWC/STAFF) is measured as the number of journal articles indexed in the databases Scopus, Current Contents and Thomson Routers to the number of faculty staff. The reputation of the faculty can also be measured by the rating (D'Este and Patel, 2007). The rating scores of Slovak university faculties can be gathered from The Academic Ranking and Rating Agency (ARRA), and the ranking is based on publicly available and verifiable data about scientific activities, faculty, student numbers, student application numbers, grants and doctoral studies. As the last rank was available for the year 2014 we used the data from this year (ARRA, 2014). Perhaps results can be intriguing, but several authors confirmed the correlation between lower rating and the corresponding higher probability of researcher's involvement in a wider variety of interactions (D'Este and Patel, 2007). If firms need to interact with researchers willing to focus on their immediate problems by helping them to apply new knowledge, less prestigious faculties may have a comparative advantage (Mansfield and Lee, 1996). Experience in externally funded research projects shows expertise in the competitive acquisition of external funds (Schartinger, Schibany and Gassler, 2001). The number of research projects financed by public authorities (PUBLIC/STAFF) or financed by the EU or another foreign grant scheme per faculty's staff (FOREIGN/STAFF) might be related to the interactions of a faculty to the business sector. The high intensity of teaching students and supervising PhD students can detract resources from the other activities including contract research. We assume a negative relationship between a faculty teaching intensity (BM/STAFF) and establishing interactions with private firms. The independent variable (PHD/PROF) is measured as the number of $\mathrm{PhD}$ students to professors and the independent variable (BM/STAFF) is measured as the number of Bachelor and Master students to academic staff. 


\section{Institutional Context}

The institutional approach attempts to explain the formation of linkages through the context in which they are embedded - the culture and environment in which the research is undertaken (Owen-Smith et al., 2002). Academic systems faced with budgetary difficulties will be more open to commercial collaborations with companies. Universities/faculties can be expected to interact differently with industry depending on their mission (Etzkowitz and Leyedesdorff, 2000). In the study, we control for the regional context by including the gross domestic expenditure on R\&D (GERD PER CAPITA). Districts with a lower gross domestic expenditure on R\&D may have fewer high-tech companies willing to finance contract research. Thus, we can expect a negative relationship between the GERD and the amount of contract research. Another aspect of the institutional context is the affiliation to a scientific discipline. Disciplinary affiliation is an important variable explaining engagement with industry (Martinelli, Meyer and Von Tunzelmann, 2008). Typically, less industrial interaction is among social disciplines, and U-I collaboration prevails in natural and technical sciences (Schartinger et al., 2002). The independent categorical variable (TYPE_FAC) indicates the type of faculty and takes the value 0 for an agricultural faculty, 1 if it is an economic faculty, and 2 for a technical faculty.

\section{DATA AND METHODOLOGY}

The study is based on a unique dataset that has been created from different data sources. The core data has been gathered from the database "The domestic and foreign grant allocation to universities" provided by the Ministry of Education, Science, Research and Sport of the Slovak Republic. The database includes basic information about the different types of research activities: domestic and foreign contract research (private entities), research grants financed by foreign grant schemes (e.g. European Commission, HORIZON 2020, Visegrad Fund etc.) and research grants financed by public grant schemes (APVV, VEGA). The data lacked information about the addresses of the firms involved in contract research, so a manual search through the public Business Register of the Slovak Republic (orsr.sk) was needed to complete missing data. The additional information regarding the number of publications and patents comes from the Central Registry of Publications Activity (crepc.sk) and information on the number of academic staff comes from the statistical yearbook provided by the Slovak Centre of Scientific and Technical Information (cvtisr.sk). Due to changes in the reporting rules, comparable information is available for the years 2014-2016. The analysis is limited to five public technical universities in Slovakia (Technical University in Košice - TUKE, Slovak Technical University in Bratislava - STUBA, Technical University in Zvolen - TUZVO, University of Žilina - UNIZA, Slovak Agriculture University in Nitra - SPU) and their faculties. The final sample includes 23 faculties and comprising more than 1,158 research contracts in total. The empirical analysis is based on an econometric 
model where the dependent variable is the average number of contracts with industry generated by each faculty between the years 2014 and 2016.

As the dependent variable (measured as the average number of contracts with industry generated by each faculty between the years 2014 and 2016) is overdispersed and contains non-zero numbers, negative binomial regression is preferred to zero-inflated Poisson regression. The estimator based on this approach can also be used for non-integer data (Santos Silva and Tenreyro, 2006). The Voung test confirms the choice. In order to address the issue of heteroscedasticity, the Huber/White estimator method was used to produce robust standard errors (White, 1982). Finally, we also tested model for multicollinearity by calculating the variance inflation factors (VIFs) for the exogenous variables. The mean VIF in the model does not exceed 10 which indicates that multicollinearity is not a concern (O'Brien, 2007).

\section{PERFORMANCE AND SPATIAL DISTRIBUTION OF CONTRACT RESEARCH}

Tab. 1 depicts the development of the different sources of funding for the selected universities in the period 2014-2016. Compared to the year 2014 (61\%), the universities' share of income from public grants has decreased in 2016 $(58 \%)$, while the total share of income generated from industry grants has increased in 2016 (24\%) compared to the year 2014 (20\%). There is no surprising volatility in the percentage of income from industry grants; a long time series is unfortunately not available. However, UNIZA's unique position in the volume of U-I industry links is strong. UNIZA and SPU have been able to increase their total income from industry from 2014 to 2016. Performance in contract research should be positively affected by launching science parks at several universities, financed from the European funds in Slovakia. AgroBioTech Research Centre focusing on applied research in the field of agrobiology, biotechnology and technology in agriculture was opened in Nitra (SPU) in 2015. University of Žilina also established Science and Technology Park in 2015. The other universities were still only preparing to open their science parks. It appears that the opening of science parks may have a positive influence on promoting the cooperation of universities and industry in R\&D activities (Ramaciotti and Rizzo, 2014). Another factor explaining the performance of UNIZA is the external environment, a highly developed regional innovation system, a dense network of R\&D organizations that play a central role in diffusing knowledge to a large number of firms (Čorej, 2006; Hudec and Prochádzková, 2018). Moreover, the Žilina region has recorded the second highest average R\&D expenditure per capita (132 EUR) between the years 2014 and 2016 (compared to 96.5 EUR in the Košice region and 86.8 EUR in the Nitra region). 
Table 1 - An Overview of Different Sources of Funding at Universities (Authors' Calculation on Data Provided by the Ministry of Education, Science, Research and Sport of the Slovak Republic)

\begin{tabular}{|c|c|c|c|c|c|c|c|c|c|}
\hline \multirow[t]{2}{*}{ University } & \multicolumn{3}{|c|}{$\begin{array}{l}\text { The share of public } \\
\text { grants in the total } \\
\text { university income in \% } \\
\text { (Absolute value in } \\
\text { thousand in EUR) }\end{array}$} & \multicolumn{3}{|c|}{$\begin{array}{l}\text { The share of foreign } \\
\text { grants in the total } \\
\text { university income in \% } \\
\text { (Absolute value in } \\
\text { thousand in EUR) }\end{array}$} & \multicolumn{3}{|c|}{$\begin{array}{l}\text { The share of industry } \\
\text { grants in the total } \\
\text { university income in \% } \\
\text { (Absolute value in } \\
\text { thousand in EUR) }\end{array}$} \\
\hline & 2014 & 2015 & 2016 & 2014 & 2015 & 2016 & 2014 & 2015 & 2016 \\
\hline SPU & $\begin{array}{l}82.0 \\
(500)\end{array}$ & 86.7 & $\begin{array}{l}32.9 \\
(500)\end{array}$ & $\begin{array}{l}11.3 \\
(64)\end{array}$ & 13.3 & $\begin{array}{l}0.8 \\
(11)\end{array}$ & $\begin{array}{l}6.8 \\
(38)\end{array}$ & NA & $\begin{array}{c}66.3 \\
(900)\end{array}$ \\
\hline STUBA & $\begin{array}{c}70.5 \\
(5,000)\end{array}$ & 79.8 & $\begin{array}{c}65.4 \\
(4,800)\end{array}$ & $\begin{array}{l}12.7 \\
(900)\end{array}$ & 9.6 & $\begin{array}{c}20 \\
(1,400)\end{array}$ & $\begin{array}{c}16.8 \\
(1,200)\end{array}$ & 10.6 & $\begin{array}{c}14.6 \\
(1,000)\end{array}$ \\
\hline TUZVO & $\begin{array}{l}88.7 \\
(500)\end{array}$ & 87.8 & $\begin{array}{l}86.9 \\
(600)\end{array}$ & $\begin{array}{l}9.7 \\
(58)\end{array}$ & 6.9 & $\begin{array}{l}12.2 \\
(89)\end{array}$ & $\begin{array}{l}1.5 \\
\text { (9) }\end{array}$ & 5.4 & $\begin{array}{l}1.0 \\
(6)\end{array}$ \\
\hline TUKE & $\begin{array}{r}49.9 \\
(1,700)\end{array}$ & 55.9 & $\begin{array}{c}61.8 \\
(2,000)\end{array}$ & $\begin{array}{l}23.1 \\
(800)\end{array}$ & 25.2 & $\begin{array}{l}22.5 \\
(700)\end{array}$ & $\begin{array}{c}27 \\
(900)\end{array}$ & 18.8 & $\begin{array}{l}15.7 \\
(500)\end{array}$ \\
\hline UNIZA & $\begin{array}{c}44.2 \\
(1,400)\end{array}$ & 49.1 & $\begin{array}{c}45.9 \\
(1,700)\end{array}$ & $\begin{array}{l}29.4 \\
(900)\end{array}$ & 9.5 & $\begin{array}{l}15.0 \\
(600)\end{array}$ & $\begin{array}{l}26.4 \\
(800)\end{array}$ & 41.3 & $\begin{array}{c}39.1 \\
(1,500)\end{array}$ \\
\hline TOTAL & $\begin{array}{c}61 \\
(9,100)\end{array}$ & 70.0 & $\begin{array}{c}58 \\
(9,700)\end{array}$ & $\begin{array}{c}18 \\
(2,700)\end{array}$ & 13.0 & $\begin{array}{c}17.0 \\
(2,900)\end{array}$ & $\begin{array}{c}20 \\
(3,000)\end{array}$ & 17.0 & $\begin{array}{c}24.0 \\
(4,000)\end{array}$ \\
\hline
\end{tabular}

Notes: Slovak Agriculture University in Nitra (SPU); Slovak Technical University in Bratislava (STUBA); Technical University in Zvolen (TUZVO); Technical University in Košice (TUKE); University of Žilina (UNIZA).

Not surprisingly, universities have most of the linkages at the intra- and interregional level (Tab. 2). Moreover, the highest share of contract research income is not in the region of their seat, confirming still undeveloped regional innovations systems. Again, UNIZA might be a role model for other universities, having the highest share of income from the international industry $(48 \%)$. Together with STUBA, they show a right balance between an inward and outward orientation towards cooperation. It seems that the universities do not pay attention towards a capacity building partnerships with regional firms and vice versa. However, further investigation would be needed to shed light on this matter. 
Table 2 - An Overview of Different Universities' Sources from Industry (Authors' Calculation on Data Provided by the Ministry of Education, Science, Research and Sport of the Slovak Republic)

\begin{tabular}{|c|c|c|c|c|c|c|c|c|c|}
\hline \multirow[t]{2}{*}{ University } & \multicolumn{3}{|c|}{$\begin{array}{l}\text { The share of inter- } \\
\text { regional industry income } \\
\text { in the total university } \\
\text { income from industry in } \\
\% \\
\text { (Absolute value in } \\
\text { thousand in EUR) }\end{array}$} & \multicolumn{3}{|c|}{$\begin{array}{l}\text { The share of intra- } \\
\text { regional industry income } \\
\text { in the total university } \\
\text { income from industry in } \\
\% \\
\text { (Absolute value in } \\
\text { thousand in EUR) }\end{array}$} & \multicolumn{3}{|c|}{$\begin{array}{l}\text { The share of } \\
\text { international industry } \\
\text { income in the total } \\
\text { university income from } \\
\text { industry in \% } \\
\text { (Absolute value in } \\
\text { thousand in EUR) }\end{array}$} \\
\hline & 2014 & 2015 & 2016 & 2014 & 2015 & 2016 & 2014 & 2015 & 2016 \\
\hline SPU & $\begin{array}{c}21.1 \\
(8)\end{array}$ & $\mathrm{NA}$ & $\begin{array}{l}99.3 \\
(900)\end{array}$ & $\begin{array}{l}40.3 \\
(15)\end{array}$ & $\mathrm{NA}$ & $\begin{array}{l}0.8 \\
(7)\end{array}$ & $\begin{array}{l}38.6 \\
(14)\end{array}$ & NA & NA \\
\hline STUBA & $\begin{array}{c}41.2 \\
(5,000)\end{array}$ & 51.5 & $\begin{array}{r}41.9 \\
(500)\end{array}$ & $\begin{array}{l}43.2 \\
(500)\end{array}$ & 39.5 & $\begin{array}{c}20 \\
(400)\end{array}$ & $\begin{array}{l}15.6 \\
(200)\end{array}$ & 9.0 & $\begin{array}{l}17.2 \\
(200)\end{array}$ \\
\hline TUZVO & $\begin{array}{l}70.1 \\
(500) \\
\end{array}$ & 99.6 & $\begin{array}{l}100 \\
(7) \\
\end{array}$ & $\begin{array}{l}29.9 \\
(2) \\
\end{array}$ & 0.4 & NA & $\mathrm{NA}$ & $\mathrm{NA}$ & NA \\
\hline TUKE & $\begin{array}{c}26.6 \\
(1,700)\end{array}$ & 23.9 & $\begin{array}{l}51.1 \\
(300)\end{array}$ & $\begin{array}{l}73.3 \\
(700)\end{array}$ & 70.5 & $\begin{array}{l}22.5 \\
(700)\end{array}$ & $\begin{array}{l}0.1 \\
(1)\end{array}$ & 5.7 & $\begin{array}{l}21.9 \\
(100)\end{array}$ \\
\hline UNIZA & $\begin{array}{c}56.9 \\
(1,400)\end{array}$ & 51.1 & $\begin{array}{l}40.9 \\
(600) \\
\end{array}$ & $\begin{array}{l}3.6 \\
(29) \\
\end{array}$ & 18.3 & $\begin{array}{l}15.0 \\
(600)\end{array}$ & $\begin{array}{l}39.5 \\
(300) \\
\end{array}$ & 30.6 & $\begin{array}{l}48.5 \\
(700)\end{array}$ \\
\hline TOTAL & $\begin{array}{c}41.0 \\
(1,300)\end{array}$ & 46.0 & $\begin{array}{c}56 \\
(2,300)\end{array}$ & $\begin{array}{c}41.0 \\
(1,200)\end{array}$ & 36.0 & $\begin{array}{l}19.0 \\
(700)\end{array}$ & $\begin{array}{l}17.9 \\
(500)\end{array}$ & 17.8 & $\begin{array}{c}25.0 \\
(1,000)\end{array}$ \\
\hline
\end{tabular}

\section{ECONOMETRIC ANALYSIS AND RESULTS}

Tab. 3 reports the model results described in Section 2. The findings support hypothesis that the age of the faculty is a determinant of the number of contracts with industry. Brand recognition and the long-term experience gives employees the specific knowledge to carry out industry tasks more efficiently and thus leading to a higher number of contracts with industry. 
Table 3 - The Estimation of the Determinants of Contract Research

\begin{tabular}{|l|c|}
\hline \multicolumn{2}{|c|}{ Organisational Context } \\
\hline F_AGE & $0.059^{* * *}(0.009)$ \\
\hline PROF/NON_PROF & $3.594 * *(1.497)$ \\
\hline SWC/STAFF & $1.310^{* *}(1.911)$ \\
\hline PUBLIC/STAFF & $0.168 * * *(0.032)$ \\
\hline FOREIGN/STAFF & $-0.0002(0.0001)$ \\
\hline BM/STAFF & $-1.707 *(0.087)$ \\
\hline PHD/PROF & $0.204 * *(0.038)$ \\
\hline ARRA & $-0.064 * *(0.021)$ \\
\hline PAT/STAFF & $-0.021(1.534)$ \\
\hline & Institutional Context \\
\hline GERD PER CAPITA & $0.205 * *(0.053)$ \\
\hline TYPE_FAC_ECONOM & $-0.597(0.969)$ \\
\hline TYPE_FAC_TECHNIC & $1.565 *(0.789)$ \\
\hline Pseudo R ${ }^{2}$ & 0.6274 \\
\hline
\end{tabular}

Notes: Robust standard errors in parenthesis. Coefficients marked with ***, ** and * are significant at $0.001,0.01$ and 0.05 level respectively. Agricultural is the reference category.

Public spending on research is positively and significantly related to the amount of contracts with industry. Both public and private expenditure on research are comparably lower in Slovakia than the EU average. An increase in public research expenditure aimed at promoting partnerships between universities and industry could have a positive impact on the formation of further research collaboration with industry and generating positive spatial spillovers. Besides, $a$ faculty's experience in international research projects financed by the EU or similar foreign grant schemes is not shown significant. Despite it, the relationship appears to be negative. The ability of a department to gain research grants from the EU is based on a fiercely peer-reviewed competitive basis. Successful faculties are taken as having high research capabilities and thus external funding substitutes public funding and private funding from industry including contract research. Alternatively, due to the high concentration on global research, necessary human capacity for contract research is not at disposal. But higher publication performance is shown to impact the propensity of forming a contract with industry, faculties conducting a high quality of research are attractive to private firms. Research universities, their knowledge and technological problemsolving capacities are trusted by industry. An interesting point is a negative relationship of the faculty reputation measured by the multidimensional rating score ARRA and the engagement with industry. Less prestigious faculties appear 
to be more open to satisfying firms' demands and more willing to solve specific problems. There is no significant effect of the patenting intensity. In engineering science, patenting is less attractive due to the lower monetary pay-offs. Therefore, academics are primarily pursued to develop relationships with firms or exploit other research-related opportunities. However, the relationship of patenting and contract research might be different in some other disciplines, patents have higher monetary value e.g. in life sciences. Further, the results confirm that a high intensity of teaching is negatively related to the propensity to establish research contracts with industry (Schartinger et al., 2002). On the contrary, a positive relationship was confirmed between a high overall number of PhD students to professors and the number of contracts with industry. This confirms that if there is a predominance of learning in the portfolio of academic activities, there is a lack of human and time capabilities, but also sufficient experience for contract research. This shows also the great importance of $\mathrm{PhD}$. students in exchange of knowledge between the academy and firms. Faculty personnel structure also exhibits a positive relationship with the number of contracts with industry. The result is consistent with the career life cycle argument that individuals who are well-established in their academic careers will be more likely to capitalise on their reputation to increase their engagement in UI activities (D'Este and Patel, 2007).

\section{CONCLUSION}

The principal focus of this paper is to identify the determinants influencing the amount of contracts with industry, filling the gap in the literature on the factors of U-I links. There is a growth from $20 \%$ to $24 \%$ in the Slovak universities' share of income from industry partners in 2016 compared to the year 2014. However, in 2015 the share has declined to $17 \%$. Still, the dominant position of income from public grants persists. The regional knowledge-producing systems are still not fully developed and open in Slovakia; faculties have a higher share of contracts with firms at the inter-regional level compared to the intra-regional level. There are only two universities, namely STUBA and UNIZA, overcoming national closure having a higher share of income generated from foreign industry partners. International collaboration enables universities to acquire complementary and diversified knowledge and thus, to support their knowledge productivity. Future research could examine origins of these bilateral linkages and formation of international networks. The results of the econometric model explain the amount of contracts with industry partners. U-I contract research performance is positively associated with a scientific productivity as expressed by the number of publications, acquired public research funding and the number of $\mathrm{PhD}$ students. Academic research forwardness together with the age factor contribute to a higher reputation and attractiveness for industry. Interestingly, the faculties that have public research grants interact with industry to a higher degree than those more funded form international funds. This is related to the capacity limit of university resources. Universities and their faculties take the strategic 
decisions on the acquisition of different types of resources (research, education, domestic grants, international grants, commercialisation of research, industry contracts, etc.) which should be reflected in the definition of their mission and portfolio of their activities. Public funding to universities thus substitutes a potential funding from industry contracts, representing a more stable and easier obtainable resource. Moreover, in Slovakia the government has not shifted the direction of budgetary funding towards more applied research exploitable by industry, still rather financing fundamental research and evaluating academic publications. Thus, universities have not been directly stimulated to set in their entrepreneurship mission and also the contract research is outside the scope of the government. Policies encouraging knowledge transfer activities should take a better account to integrate the third university's mission with the priorities of teaching, research and producing publications. However, government policies still consider third mission as complementary in nature. Due to the lack of longitudinal data, we could not control for reverse causality between the publishing intensity and the number of contracts. It is questionable whether faculty scientific productivity is enhanced by its engagement with industry or vice versa, industry engagement is impacted by high research performance. The limitations in terms of inferring causal relationships between variables could be solved by using panel data on academic patents and publications to take into account the time dimension.

\section{ACKNOWLEDGEMENTS}

This work was supported by the Slovak Research and Development Agency under the contract No. APVV-14-0512.

\section{REFERENCES}

Ankrah, S. and AL-Tabbaa, O., 2015. Universities-Industry Collaboration: A Systematic Review. Scandinavian Journal of Management, 31(3), pp.387-408. http://dx.doi.org/10.1016/j.scaman.2015.02.03.

ARRA, 2014. Hodnotenie fakúlt vysokých škôl 2014. [pdf] Bratislava: Akademická rankingová a ratingová agentúra (ARRA). Available at: $<$ http://www.arra.sk/sites/arra.sk/files/file/ARRA_Sprava_2014.pdf $>$ [Accessed 15 November 2018].

Audretsch, D.B., 2014. From the Entrepreneurial University to the University for the Entrepreneurial Society. The Journal of Technology Transfer, 39(3), pp.313321. http://dx.doi.org/10.1007/s10961-012-9288-1.

Capaldo, G., Costantino, N., Pellegrino, R., and Rippa, P., 2016. Factors Affecting the Diffusion and Succss of Collaborative Interactions between University and Industry. Journal of Science and Technology Policy Management, 7(3), pp.273-288. http://dx.doi.org/10.1108/JSTPM-12-2015-0038. 
Carayannis, E.G., Rogers, E.M., Kurihara, K. and Allbritton, M.M., 1998. High technology spin-offs from government $\mathrm{R} \& \mathrm{D}$ laboratories and research universities. Technovation, 18(1), pp.1-11. http://dx.doi.org/10.1016/S01664972(97)00101-6.

Cohen, W.M., Nelson, R.R. and Walsh, J.P., 2002. Links and Impacts: The Influence of Public Research on Industrial R\&D. Management Science, 48(1), pp.1-23. http://dx.doi.org/10.1287/mnsc.48.1.1.14273.

Čorej, J., 2006. Univerzity, priemysel a partnerstvo: doktorandské štúdium a transfer poznatkov. Žilina: Žilinská univerzita.

D'Este, P. and Patel, P., 2007. University-Industry Linkages in the UK: What are the Factors Underlying the Variety of Interactions with Industry?. Research Policy, 36(9), pp.1295-1313. http://dx.doi.org/10.1016/j.respol.2007.05.002.

Dutrénit, G., and Arza, V., 2010. Channels and Benefits of Interactions between Public Research Organisations and Industry: Comparing four Latin American Countries. Science and Public Policy, 37(7), pp.541-553. http://dx.doi.org/10.3152/030234210X512043.

Etzkowitz, H. and Leyedesdorff, L., 2000. The Dynamics of Innovation: From National Systems and "Mode 2" to a Triple Helix of University-IndustryGovernment Relation. Research Policy, 29(2), pp.109-123. http://dx.doi.org/10.1016/S0048-7333(99)00055-4.

Franzoni, C. and Lissoni, F., 2009. Academic Entrepreneurs: Critical Issues and Lessons for Europe. In: A. Varga, ed. 2009. Universities, Knowledge Transfer and Regional Development: Geography, Entrepreneurship and Policy. Northampton, MA; USA Cheltenham, UK: Edward Elgar. pp.163-190.

Furman, J.L., Porter, M.E. and Stern, S., 2002. The Determinants of National Innovative Capacity. Research Policy, 31(6), pp.899-933. http://dx.doi.org/10.1016/S0048-7333(01)00152-4.

Giuliani, E., Morrison, A., Pietrobelli, C. and Rabellotti, R., 2010. Who Are the Researchers that Are Collaborating with Industry? An Analysis of the Wine Sectors in Chile, South Africa and Italy. Research Policy, 39(6), pp.748-761. http://dx.doi.org/10.1016/j.respol.2010.03.007.

Hottenrott, H. and Thorwarth, S., 2011. Industry Funding of University Research and Scientific Productivity. Kyklos, 64(4), pp.534-555. https://doi.org/10.1111/j.1467-6435.2011.00519.x.

Hudec, O. and Prochádzková, M., 2018. The Evolution of Innovation Networks in Slovakia: Disintegration and Slow Recovery. In: J. Stejskal, P. Hajek, O. Hudec, eds. 2018. Knowledge Spillovers in Regional Innovation Systems. Advances in Spatial Science (The Regional Science Series). Cham: Springer. pp.133-161. 
Hudec, O., 2015. Visegrad Countries and Regions: Innovation Performance and Efficiency. Quality Innovation Prosperity, 19(2), pp.55-72.

Hudec, O., 2017. A Ranking-Free Evaluation of Universities: An Intellectual Capital Approach. In: IEEE, 15th IEEE International Conference on Emerging eLearning Technologies and Applications. Stary Smokovec, Slovakia, 26-27 October 2017. Danvers, MA: IEEE.

Hunady, J., Orviska, M. and Pisar, P., 2018. The Effect of Higher Education on Entrepreneurial Activities and Starting Up Successful Businesses. Engineering Economics, 29(2), pp.226-235. http://dx.doi.org/10.5755/j01.ee.29.2.19069.

Jensen, R. and Thursby, M., 2001. Proofs and Prototypes for Sale: The Licensing of University Inventions. Amer. Econom. Rev., 91(1), pp.240-259.

Kwiek, M., 2012. Changing Higher Education Policies: From the Deinstitutionalization to the Reinstitutionalization of the Research Mission in Polish Universities. Science and Public Policy, 39(5), pp.641-654. http://dx.doi.org/10.1093/scipol/scs042.

Lee, Y.S., 2000. The Sustainability of University-Industry Research Collaboration: An Empirical Assessment. Journal of Technology Transfer, 25(2), pp.111-153. http://dx.doi.org/10.1023/A:100789532.

Mansfield, E. and Lee, J.-Y., 1996. The modern university: contributor to industrial innovation and recipient of industrial R\&D support. Research Policy, 25(1), pp.1047-1058.

Martinelli, A., Meyer, M. and Von Tunzelmann, N., 2008. Becoming an Entrepreneurial University? A Case Study of Knowledge Exchange Relationships and Faculty Attitudes in a Medium-Sized, Research-Oriented University. Journal of Technology Transfer, 33(3), pp.259-283.

McAdam, R., Miller, K., McAdam, M. and Teague, S., 2012. The development of University Technology Transfer stakeholder relationships at a regional level: Lessons for the future. Technovation, 32(1), pp.57-67.

Meyer-Krahmer, F. and Schmoch, U., 1998. Science-Based Technologies: University-Industry Interactions in four Fields. Research Policy, 27(8), pp.835851. http://dx.doi.org/10.1016/S0048-7333(98)00094-8.

Novotny, Á., 2008. Academic Entrepreneurship in Hungary: Can the Bayh-Dole Model of University Technology Transfer Work in an Eastern European Context?. Periodica Polytechnica, 16(2), pp.71-80. http://dx.doi.org/10.3311/pp.so.2008-2.03.

O'Brien, R.M., 2007. A Caution Regarding Rules of Thumb for Variance Inflation Factors. Quality \& Quantity, 41(5), pp.673-690. http://dx.doi.org/10.1007/s1135-006-9018-6. 
Owen-Smith, J., Riccaboni, M., Pammolli, F. and Powell, W.W., 2002. A Comparison of U.S. and European University-Industry Relations in the Life Sciences. Management Science, 48(1), pp.24-43. http://dx.doi.org/10.1287/mnsc.48.1.24.14275.

Perkmann, M. and Walsh, K., 2007. University-Industry Relationships and Open Innovation: Towards a Research Agenda. International Journal of Management Reviews, 9(4), pp.259-280. http://dx.doi.org/10.1111/j.1468-2370.2007.00225.x.

Perkmann, M. et al., 2013. Academic Engagement and Commercialisation: A review of the Literature on University and Industry Relations. Research Policy, 42(2), pp.423-442. http://dx.doi.org/10.1016/j.respol.2012.09.007.

Phan, P.H. and Siegel, D.S., 2006. The Effectiveness of University Technology Transfer: Lessons Learned from Qualitative and Quantitative Research in the US and UK. Foundations and Trends in Entrepreneurship, 2(2), pp.66-114. http://dx.doi.org/10.1561/0300000006.

Prokop, V., Stejskal, J. and Kuvíková, H., 2017. The Different Drivers of Innovation Activities in European Countries: A Comparative Study of Czech, Slovak, and Hungarian Manufacturing Firms. Ekonomický časopis, 65(1), pp.3145. http://dx.doi.org/10.5755/j01.ee.28.1.16111.

Ramaciotti, L. and Rizzo, U., 2014. The determinants of academic spin-off creation by Italian universities. $R \& D$ Management, 45(5), pp.501-514. http://dx.doi.org/10.1111/radm.12105.

Roessner, J.D., 1993. What companies want from the Federal labs. Issues in Science and Technology, 10(1), pp.37-42.

Rothaermel, F.T., Agung, S. and Jiang, L., 2007. University Entrepreneurship: A Taxonomy of the Literature. Industrial and Corporate Change, 16(4), pp.6911180. http://dx.doi.org/10.1093/icc/dtm023.

Santos Silva, J.M.C. and Tenreyro, S., 2006. The Log of Gravity. The Review of Economics and Statistics, 88(4), pp.641-658.

Schartinger, D., Rammer, Ch., Fischer, M.M. and Fröhlich, J., 2002. Knowledge Interactions between Universities and Industry in Austria: Sectoral Patterns and Determinants. Research Policy, 31(3), pp.303-328. http://dx.doi.org/10.1016/S004/-7333(01)00111-1.

Schartinger, D., Schibany, A. and Gassler, H., 2001. Interactive Relations Between Universities and Firms: Empirical Evidence for Austria. Journal of Technology Transfer, 26(3), pp.255-268.

Schiuma. G. and Lerro. A., 2008. Knowledge-Based Capital in Building Regional Innovation Capacity. Journal of Knowledge Management, 12(5), pp.121-136. http://dx.doi.org/10.1108/13673270810902984. 
Sengupta, A. and Ray, A.S., 2017. University Research and Knowledge Transfer: A Dynamic View of Ambidexterity in British Universities. Research Policy, 46(5), pp.881-897. http://dx.doi.org/10.1016/j.respol.2017.03.003.

Shane, S.A., 2004. Academic Entrepreneurship: University Spinoffs and Wealth Creation. Cheltenham: Edward Elgar.

Spithoven, A., 2016. Industrial Contract Research to Universities: Determinants and Spatial Dimension. Brussels: Brussels Studies Institute.

White, H., 1982. Maximum Likelihood Estimation of Misspecified Models. Econometrica, 50(1), pp.1-25. http://dx.doi.org/10.2307/1912526.

\section{ABOUT AUTHORS}

Ing. Slávka Klasová, PhD. - Assist. Professor at the Department of Regional Science and Management. Faculty of Economics, Technical University of Košice. E-mail: slavka.klasova@tuke.sk

Ing. Iveta Korobaničová, Ph.D. - Assist. Professor at the Department of Regional Science and Management. Faculty of Economics, Technical University of Košice. E-mail: iveta.korobanicova@tuke.sk

Prof. RNDr. Oto Hudec, PhD. - Professor at the Department of Regional Science and Management. Faculty of Economics, Technical University of Košice. E-mail: oto.hudec@tuke.sk. Author's ORCID: orcid.org/0000-00028877-8647.

(C) 2019 by the authors. Submitted for possible open access publication under the terms and conditions of the Creative Commons Attribution (CC-BY) license (http://creativecommons.org/licenses/by/4.0/). 